\title{
FRONTS IN THE YELLOW AND EAST CHINA SEAS: THE CASE STUDY
}

\author{
Kazmin A.S. \\ Shirshov Institute of Oceanology, Russian Academy of Sciences, \\ 36 Nahimovskiy prospekt, Moscow, 117997,Russia,e-mail: akazmin@ocean.ru \\ Submitted 24.05.2018, accepted 30.08.2018
}

\begin{abstract}
Monthly-mean high-resolution satellite sea surface temperature (SST) measurements (PATHFINDER dataset) for the period of 1982-2009 along with the selected satellite infrared and visible images have been used to update and extend the knowledge of the structure, mesoscale features, seasonal and interannual variability of the fronts in the Yellow and East China Seas. The patterns of the general circulation, frontogenesis processes and phenomenology of the fronts are outlined. Seasonal variability of the selected most prominent local fronts has been documented. The major result is that when the climatological averaging is applied, the fronts at the boundary of East China Sea (Taiwan front, Kuroshio frontal zone and Tsushima front) appear as unified dominating frontal structure. This structure is about $1200 \mathrm{~km}$ length, spreads along the continental shelf from Taiwan to Tsushima and separates productive sea waters from the oligotrophic oceanic waters. This frontal structure appears as a persistent coherent feature throughout the year. However, it reveals seasonal variability of the SST gradient intensity. Maximum intensity is observed during the cold season (JanuaryApril), when the SST contrasts between the warm waters of Kuroshio and cooling waters of East China Sea are the highest. To study the long-term variability of this frontal system, the maximum meridional gradient of SST in the area of Kuroshio frontal zone in February have been calculated. The results reveal an existence of the pronounced interannual variability of SST gradient with the periods consistent with the ENSO (4-5 years). Statistically significant positive correlation $(R=0.57, p<0.01)$ between the SST gradient and Multivariate ENSO Index (MEI) was found.
\end{abstract}

Keywords: Sea fronts; Mesoscale variations; Seasonal variability; Long-term changes; Atmospheric forcing; Yellow and East China Seas

\section{Introduction}

Yellow and East China Seas are typical marginal seas, opened for interaction with the ocean and experiencing a direct impact of the oceanic processes. Accordingly, fronts of various nature and scales (from local small-scale tidal fronts to large-scale oceanic frontal zone of Kuroshio) formed by a wide range of physical processes coexist within a relatively small basin. It makes this area an exceptionally interesting object for the frontal study.

Frontal research in Yellow and East China Seas are of both scientific and practical interest, since the frontal dynamics influences process of productivity and pollution transport, which is extremely important for the countries of this region. Fragmentary information on the major features of hydrology and fronts of the Yellow and East China Seas have been presented in (Zheng, Klemas, 1982; Beardsley et al., 1983; Mao Hanil et al., 1983; Hu Dunxin, 1984; Milliman et al., 1984; Pan et al., 1987; Byun, Chang, 1988; 
Kuroda et al., 1988; Sha, Xu, 1988; Xu, Sha, 1988; Lie, 1989; Kazmin, 1993; Belkin, Cornillon, 2003; Belkin et al., 2009). However, most of the above-cited studies were based on low-resolution in situ data (except for a few works, based on satellite data, e.g., Kazmin, 1993; Hickox, 2000; Belkin, Cornillon, 2003; Belkin et al., 2009) and provide only basic insight on the frontal patterns. Also, an information on temporal variability (especially, the seasonal and long-term ones) of the fronts in Yellow and East China Seas is limited (seasonal variability was mentioned in Hickox et al., 2000; Belkin et al., 2009; Chen, 2009; Kazmin, 2016).

For the first time, scheme of the general circulation and conditions of the frontogenesis in the Yellow and East China Seas, compiled from some of the above-cited studies and interpretation of satellite infrared (IR) and visible images, was presented by (Kazmin, 1993). The first elaborated scheme of SST fronts in the Yellow and East China Seas, based on the regular satellite SST measurements has been published by (Hickox et al., 2000). It was the first paper, in which a new rigorous method (which used along-frontal envelopes of frontal spatial variability) was proposed and implemented for evaluating the cross-frontal ranges of any oceanographic parameters. In addition, they mentioned seasonal variability of cross-frontal differences of the SST (but not the SST gradient, which is the major characteristic of the fronts). Later (Belkin et al., 2009) composed a simplified scheme of the fronts in Yellow and East China Seas which was, in general, consistent with that one presented earlier by (Kazmin, 1993, Hickox et al., 2000). Chen, 2009 prepared the maps of temperature, salinity and nutrient distribution and, for the first time, systematically identified the nutrients fronts in Bohai, Yellow and East China Seas.

Previous studies, based on the ship measurements along with a few satellite IR and visible images, mainly demonstrated the patterns of synoptical spatio-temporal variability of the fronts in Yellow and East China Seas. Regular high-resolution satellite SST measurements are now available since 1982, which provides an opportunity to investigate the fronts in this area in more details and on a longer time scale. The goals of this study are: (1) to update and complement the scheme of the general circulation and conditions of the frontogenesis in Yellow and East China Seas; (2) to investigate the patterns of synoptical and seasonal variability of the most prominent local fronts in Yellow and East China Seas and to summarize their parameters; (3) to reveal an existence of the unified frontal structure at the oceanic border of East China Sea and explore its seasonal and interannual variability.

\section{Data and processing}

In this paper, the high-resolution ( $9 \mathrm{~km}$ by $9 \mathrm{~km}$ ) satellite SST measurements obtained by AVHRR (Advanced Very High Resolution Radiometer) sensor from NOAA satellites (PATHFINDER dataset; Casey et al., 2010) along with the satellite IR and visible images have been used. Monthly climatology (1982-2008) and monthly-mean SST for the period of 1982-2009 for the Yellow and East China Seas basins were obtained from NOAA National Oceanographic Data Center (NODC; URL: http://data.nodc.noaa.gov/las/getUI.do). As an 
estimate of the fronts intensity in analyzed area we used the magnitude of maximum zonal or meridional (depending on the spatial orientation of the fronts) SST gradient $(G=|\partial(S S T) / \partial x|$, or $G=|\partial(S S T) / \partial y|)$. It is appropriate when fronts have almost zonal or meridional orientation, which was observed in our cases (e.g., replacement of the gradient magnitude by its component in case of inclination of the front line by $20^{\circ}$ from meridian/ parallel leads to negligible error of 5\%; in our cases this inclination was significantly less).

Multivariate ENSO Index (MEI) was obtained from NOAA Earth System Research Laboratory (URL: http://www.esrl.noaa.gov/psd/enso/mei).

Monthly-mean concentration of chlorophyll from NASA Sea-viewing Wide Field-of-view Sensor (SeaWiFS) Project was obtained at NOAA NODC site (URL: http://data.nodc.noaa.gov/las/getUI.do).

Correlation analysis (similar to that one applied by Kazmin, 2017 for assessment of atmospheric forcing upon the long-term variability of climatic oceanic frontal zones) was used to identify relation between G and MEI. Statistical significance of the results was estimated using check of null hypothesis with the Student's t-test. Because of the short data set $(N=28)$ and applied smoothing, obtained correlation was additionally tested by calculation of correlation coefficient for series with the reduced degrees of freedom and Spearman's rank correlation coefficient. For the data with a reduced number of degrees of freedom, the correlation remained significant up to $N-8=20$ with a probability level $p$ of less than 0.05 . Spearman's rank correlation coefficient was lower than Pearson's coefficient, but remained statistically significant with less than a 0.05 probability level. In general, the positive result of additional analysis provides a confidence in the conclusions based on correlation analysis.

\section{Local fronts in the Yellow and East China Seas}

Scheme of the general circulation and conditions of the frontogenesis in the Yellow and East China seas, based on compilation of above-cited studies and satellite data interpretation is presented in Fig. 1.

The most prominent feature of hydrological regime in the region is an interaction of warm and saline oceanic waters, advected northward by Kuroshio branches, with cold, less saline waters, locally formed in the shallow marginal seas. Hydrological regime is also influenced by strong seasonal variability of the atmospheric forcing, significant river discharge and intensive tidal mixing. As a result, fronts of various nature and scales (from local small-scale tidal fronts to large-scale oceanic frontal zone of Kuroshio) formed by a wide range of physical processes coexist within a relatively small basin of the Yellow and East China seas.

Warm and saline oceanic waters are advected in the area by three main northward branches of the Kuroshio: warm Taiwan Current (WTC), Yellow Sea warm current (YSWC) and Tsushima current (TSC). Compensatory circulation of the cold, freshened waters of Yellow and East China Seas is provided by southward coastal currents. 


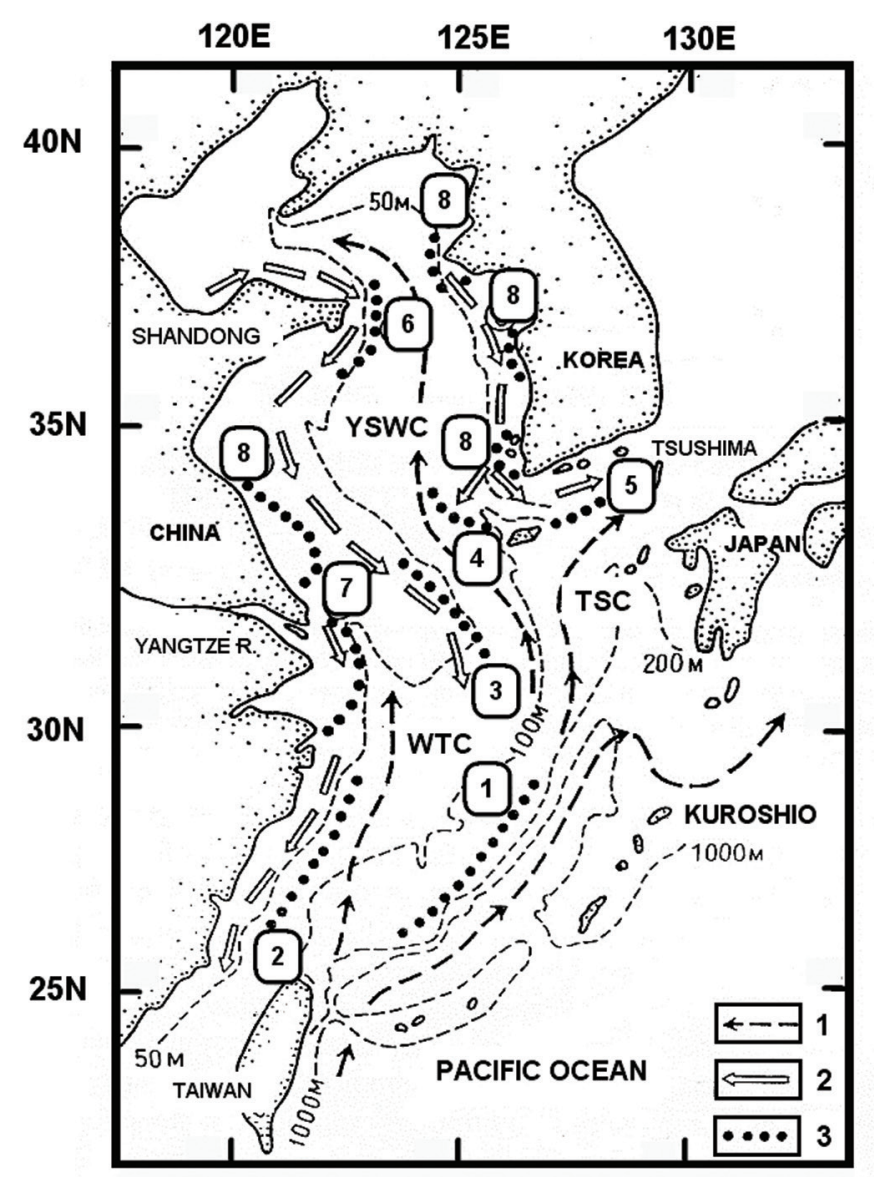

Fig. 1. The scheme of the general circulation and conditions of frontogenesis in the Yellow and East China Seas. Legend in the right bottom corner: 1 - warm and saline currents; 2 - cold and desalinated currents; 3 - frontal zones. Fine dashed lines - isobaths. WTC - warm Taiwan current. TSC - Tsushima current. YSWC - Yellow Sea warm current. Numbers in the boxes:

(1) - Kuroshio frontal zone (KFZ); (2) - front between the WTC and cold coastal current (Taiwan front - TF); (3) - front between the south-western boundary of YSWC and coastal current of Yellow Sea; (4) - front between the north-eastern boundary of YSWC and southwestern branch of cold coastal current along the western coast of Korea; (5) - front between the TSC and cold coastal current along the southern part of Korea peninsula (Tsushima front TSF); (6) - Shandong coastal front; (7) Yangtze River estuarine front; (8) coastal tidal fronts.

Thermohaline characteristics of the Kuroshio waters are stable throughout the year $\left(20-26^{\circ} \mathrm{C}\right.$ and $34-34.5 \%$ in the surface layer). On the contrary, surface layer of Yellow and East China Seas is experiencing strong seasonal fluctuations of temperature (from $2-3{ }^{\circ} \mathrm{C}$ in winter to $20-29^{\circ} \mathrm{C}$ in summer). Salinity here may vary within $30-33.5 \%$, decreasing considerably near the Huang He River mouth.

Northward propagation of the Kuroshio branches is significantly affected by the seasonal variability of the winds: south-western winds, prevailing in summer contribute to warm currents intensification and the penetration of YSWC as far north as to the Bohai Bay; in winter, the north-western winds contribute to the weakening of the northward currents. The main fronts are formed in the areas of convergence of warm and cold 
currents. Phenomenology of fronts in the Yellow and East China Seas is described below. Numbering used below corresponds to the Fig.1 caption:

(1) Kuroshio frontal zone (KFZ) is typical large-scale climatic oceanic frontal zone, located along the continental slope of the East China Sea in the 0-600 m layer (Beardsley at al., 1983; Kuroda et al., 1988). Seasonal and interannual variability of this frontal zone is described below in the section 4 .

(2) front between WTC and cold coastal current, extended along the Chinese coast from Taiwan to Yangtze River estuary (Taiwan front - TF). This front is the boundary between the coastal water mass, freshened by the Yangtze River discharge, and the warm and more saline water mass of WTC, and is persistent throughout the year. SST contrast reaches a maximum value (up to $8^{\circ} \mathrm{C}$ ) in winter. However, in summer it is also sufficient for visualization of the front on the IR images. Seasonal variability of the SST gradient (G) of the TF is shown in Fig. 2 (black line). Coastal current is also apparent on the images in visible part of the spectrum in the form of a strip of waters of high turbidity (due to the spreading of the suspended matter from the Yangtze River estuary), contrasting with clear waters of the WTC.

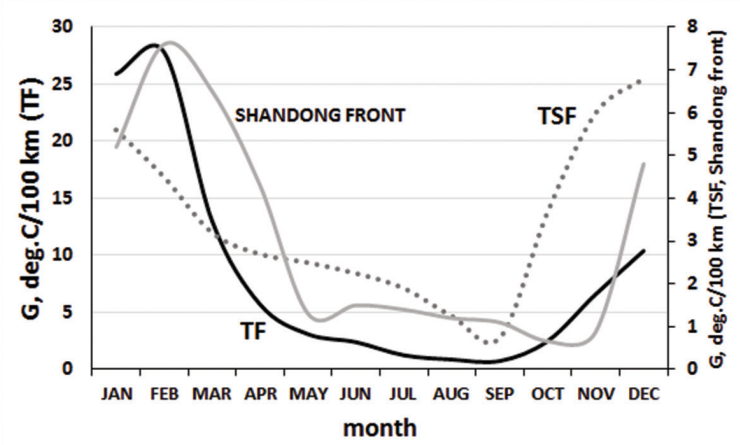

Fig. 2. Seasonal variability of the selected local fronts in the Yellow and East China Seas. Black line - Taiwan front (TF; section along the $28^{\circ} \mathrm{N}$ ). Gray line - Shandong front (section along the $36.5^{\circ} \mathrm{N}$ ). Dotted gray line - Tsushima front (TSF; section along the $128^{\circ} \mathrm{E}$ ). Left y-axis is for TF. Right y-axis is for TSF and Shandong front.

Local seasonal subsurface upwelling associated with the summer strengthening of TWC took place at the coastal side of the front. Upwelling is manifested in the rise of pycnocline which separates in summer surface and deep-water masses of TWC (not to be confused with the seasonal thermocline, located much closer to the surface). Normally, this upwelling does not reach the surface (Pan et al., 1987). However, cold deep water can reach the surface occasionally, in the dynamic situation contributing to the intensification of upwelling (e.g., when strengthening of the upwelling favorable southern wind took place). Such a situation was observed in the last decade of July 1986. On July 20, there was a sharp increase of meridional (southern) component of the wind (Fig. 3) that contributed to emergence of cold deep water at the surface and formation of band of coastal upwelling with a width of about 40-50 km. This band was apparent on the IR image for July 20 (Fig. 4, left). Later wind weakened, however, from July 23 a new upsurge began (Fig. 3) that led to further strengthening of the upwelling. Image for July 25 (Fig. 4, right) 


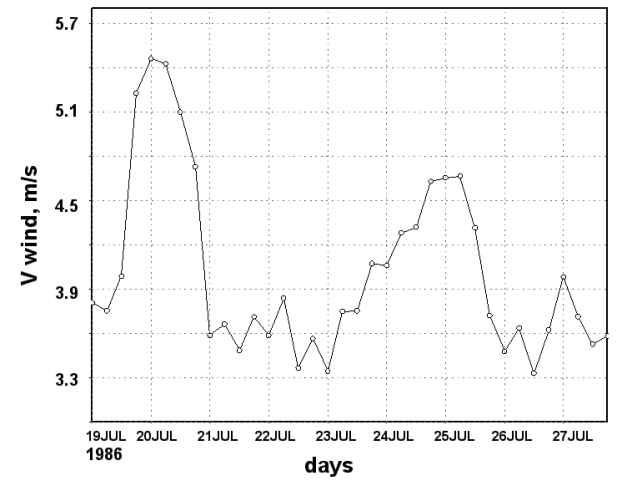

Fig. 3. Variability of the meridional component of wind speed $(\mathrm{V}, \mathrm{m} / \mathrm{s})$ at $1000 \mathrm{mb}$ in the period of July

19-27, 1986 (NCEP-NCAR re-analysis data).

shows coastal band of cold water extended to $60-80 \mathrm{~km}$ offshore. A prominent feature of the upwelling front, not reported earlier for this specific location, is the development of instability in the form of cold transverse jets extending from shore towards open sea (such jets in the other areas of coastal upwelling is fairly well known, e.g., Kostianoy and Zatsepin, 1996). Sequential images demonstrate formation (Fig. 4, left) and spreading of jets in normal to coast direction toward the open sea (Fig. 4, right). Propagation velocity of heads of the jets off shore was about $40 \mathrm{~km} /$ day, and maximum propagation was up to $250 \mathrm{~km}$.
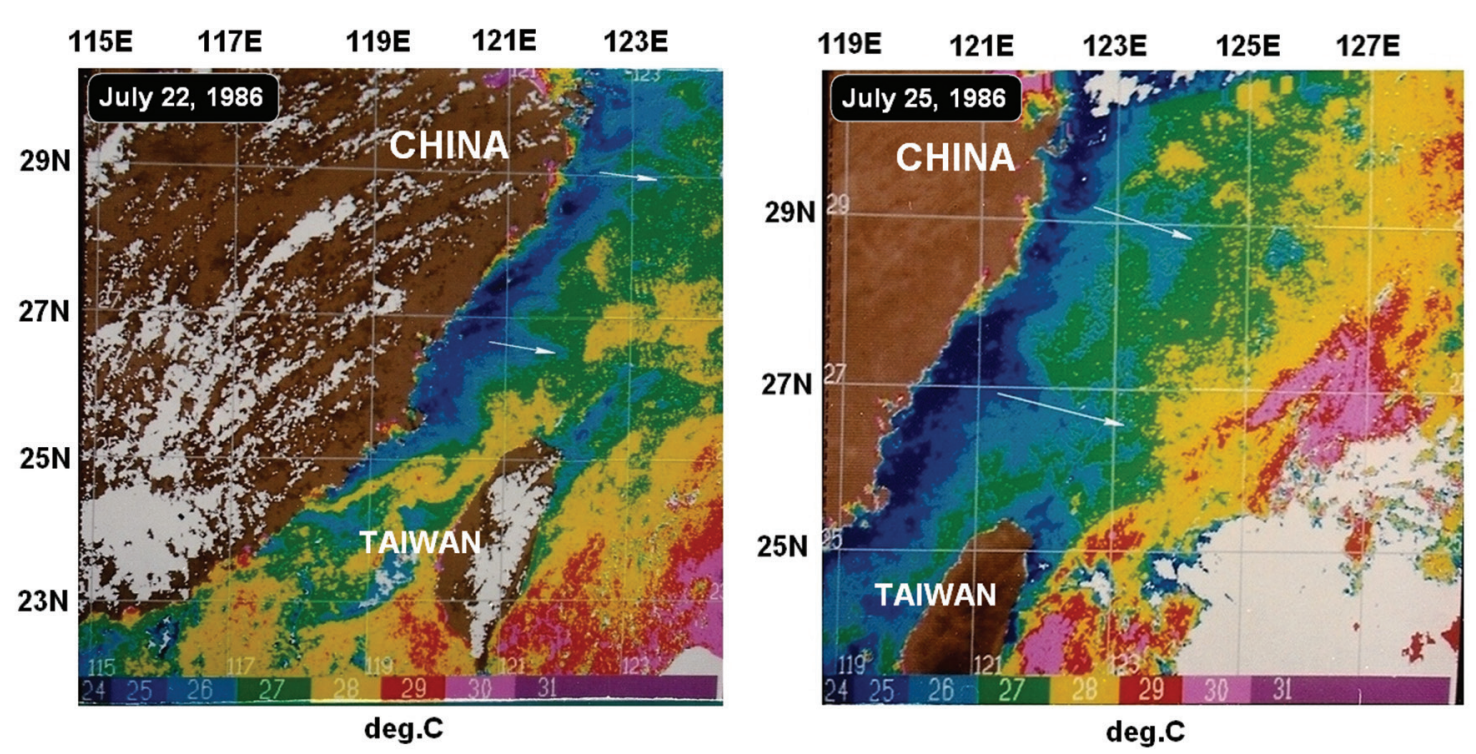

Fig. 4. SST at the east coast of China near Taiwan on July 22 (left panel) and July 25 (right panel) of 1986 (IR images from AVHRR at NOAA-9 satellite). White arrows indicate the direction of propagation of the cold lateral jets in the coastal upwelling.

(3) front between south-western boundary of YSWC and coastal current of the Yellow Sea. Its orientation, position, spatial extent and intensity is unstable and depends on season and specific hydro-meteorological situation.

(4) front on north-eastern border of YSWC, originating from convergence of YSWC and South-Western branches of flow of cold coastal waters along the western coast of Korea peninsula. This front is oriented nearly zonally, may extend to the central part of 
the East China Sea and often shows signs of intensive cross-frontal exchange in the form of interpenetration of warm and cold jets and eddies with a spatial scale of $20-50 \mathrm{~km}$.

(5) front in Tsushima Strait between TSC and cold coastal current along the southern coast of Korea (Tsushima front - TSF). It is well expressed in SST field, demonstrates active meandering and eddy formation, and is persistent throughout the year. Seasonal variability of TSF is shown in Fig. 2 (dotted line).

(6) Shandong coastal front - a semicircle structure front at the eastern tip of the Shandong Peninsula. It separates the warm and saline water of YSWC and cold, desalinated water of the coastal current directed from Bohai Bay into the Yellow sea. This front is well identifiable on both the IR and visible images (due to the high turbidity of coastal waters containing a Huang He River discharge). It is most pronounced at the northeastern tip of Shandong Peninsula. Seasonal variability of Shandong coastal front is presented at Fig. 2 (gray line).

(7) discharge front of the Yangtze River, which separates freshened by river discharge coastal waters and more saline open sea waters. Easily recognizable in the fields of SST and suspended solids matter concentration (visible images).

(8) coastal fronts of tidal origin. This type of fronts exists in summer and represent boundary between well mixed (and, therefore, colder due to tidal friction) coastal waters and stratified waters of the open part of the sea (Fearnhead, 1975). The latter have a higher temperature due to intense heating of the upper homogeneous layer bounded from below by seasonal thermocline. Main areas of formation of tidal fronts are located at the western coast of Korea Peninsula (Beardsley et al., 1983; Lie, 1989). Fronts of this type are well expressed on both IR and visible images, since intensive tidal mixing contributes to resuspension of bottom sediments. Tidal mixing also causes formation of sharp temperature contrasts of frontal type on the border of shoal (depths less than $10 \mathrm{~m}$ ) off the east coast of China between $32^{\circ} \mathrm{N}$ and $34^{\circ} \mathrm{N}$, formed by sediments of Huang He River (the old mouth of which was located in this area). However, in summer distribution of SST observed here is opposite to situation at Korean coast. Thickness of the layer of water on shoal is less than thickness of upper homogeneous layer in the open sea waters and, accordingly, in summer the coastal waters warm up much stronger. Reverse situation is observed in winter: shallow water cools much stronger than the neighboring deep water.

This generalized scheme provides a base for interpretation of satellite data in the Yellow and East China Seas basins. Elements of hydrological structure outlined above consistently appear on the IR data during cold period of the year and are confidently identifiable, though the specific characteristics of these structures vary significantly. In summer, observed patterns are less clear due to the fact that surface waters of both seas are strongly heated and contrasts between them and waters of the Kuroshio current branches diminish. Table summarizes phenomenological and some quantitative characteristics of the above-mentioned local fronts. 


\section{Frontal system at the boundary of East China Sea}
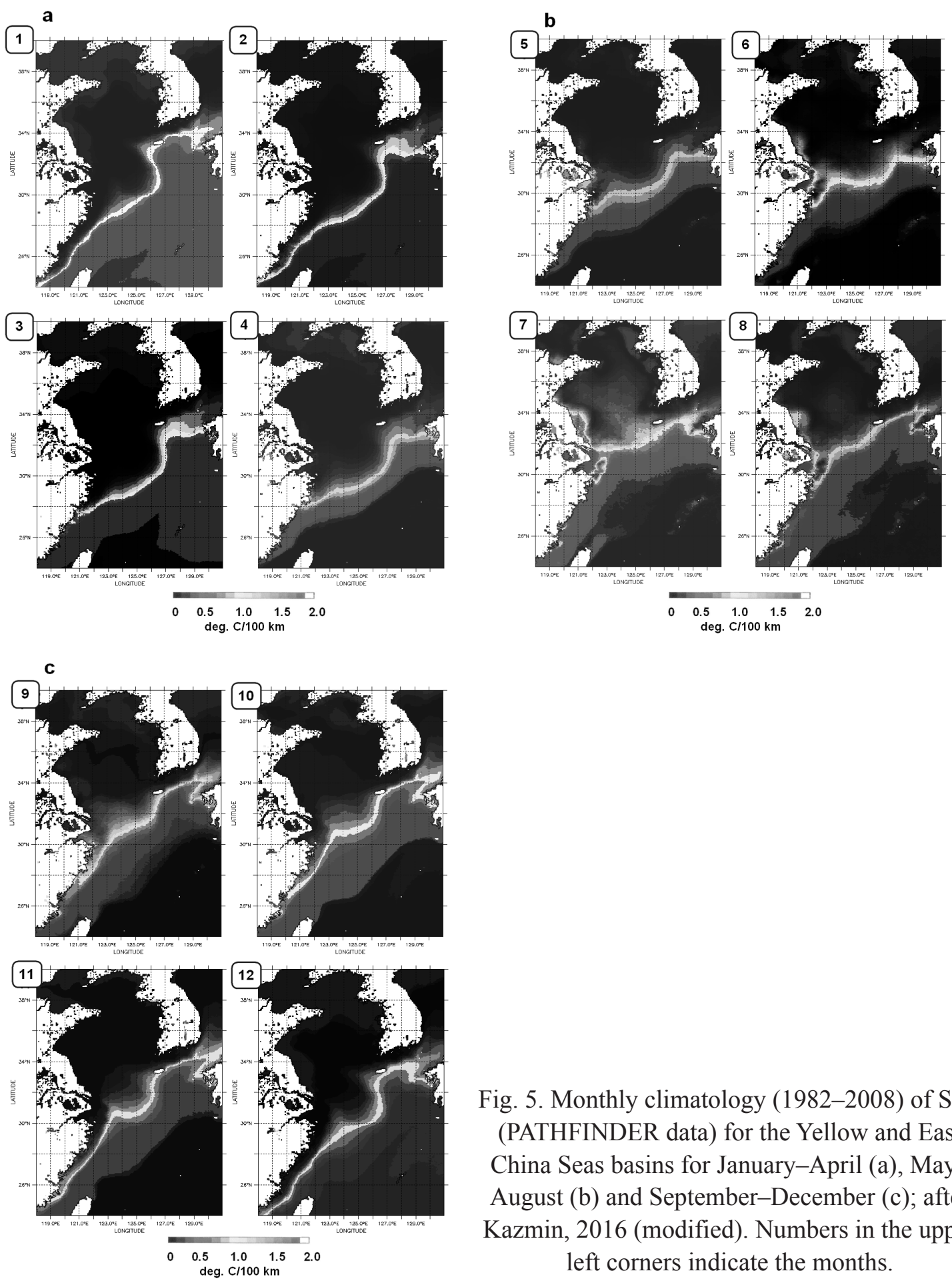

Fig. 5. Monthly climatology (1982-2008) of SST (PATHFINDER data) for the Yellow and East China Seas basins for January-April (a), MayAugust (b) and September-December (c); after Kazmin, 2016 (modified). Numbers in the upper left corners indicate the months.

Fig. 5 demonstrates monthly climatology of SST for the Yellow and East China Seas basins, modified in such a way as to highlight the dominant fronts and their seasonal variability. Narrow stripes of different shades of grey on these maps correspond to the areas of isotherms concentration, marking the position of frontal zones (lighter color 
corresponds to higher intensity of the fronts). Our analysis show that when climatological averaging is applied, the major fronts at the boundary of East China Sea (i.e., Taiwan front, Kuroshio frontal zone and Tsushima front) appear as unified dominating frontal structure. This structure is about $1200 \mathrm{~km}$ length, spreads along the continental shelf from Taiwan to Tsushima and separates productive sea waters from oligotrophic oceanic waters. Frontal structure exists as a persistent coherent feature during the whole year but reveals seasonal variability of the SST gradient intensity. Maximum intensity is observed during the cold period (January-April), when SST contrasts between the warm waters of Kuroshio and cooling waters of East China Sea are the highest. Seasonal variability of the abovementioned frontal structure in the area of its major segment (i.e., KFZ) is shown in Fig. 6.

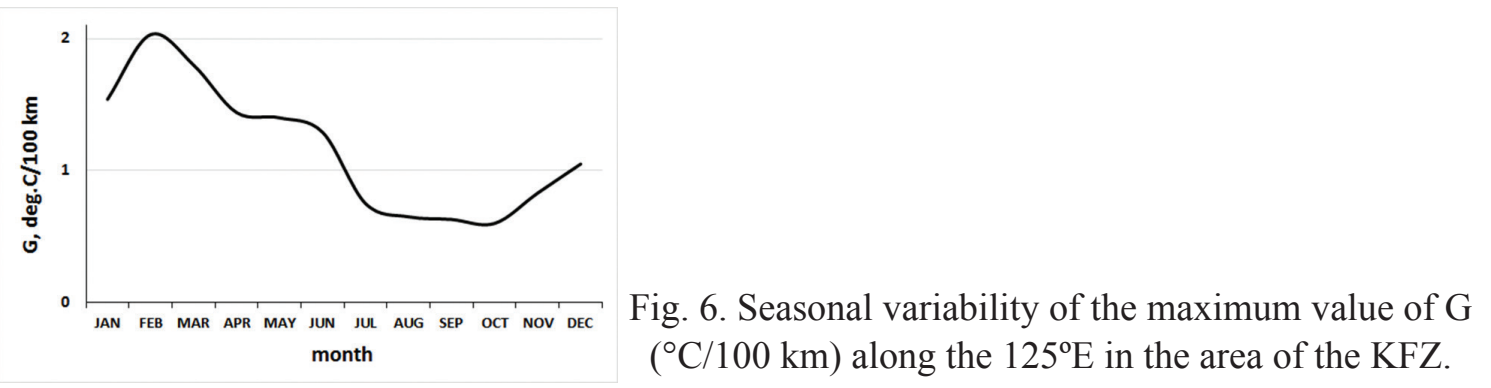

In warm period (July-November) the temperature contrasts decrease and intensity of the frontal zone is reduced. Also, the surface manifestations of Taiwan front disappear. However, in general, examined frontal structure in the climatological terms maintains its coherence and stable position throughout the year and dominates in this area.

Iimportance of this frontal structure and its long-term variability from the point of view of its impact on ecosystem of the region is that it is a natural border between the highly productive waters of Yellow and East China Seas and oligotrophic waters of the open Pacific Ocean (Fig. 7). In this illustration, the concentration of chlorophyll in a highly productive marine water is indicated by gradations of colors from green

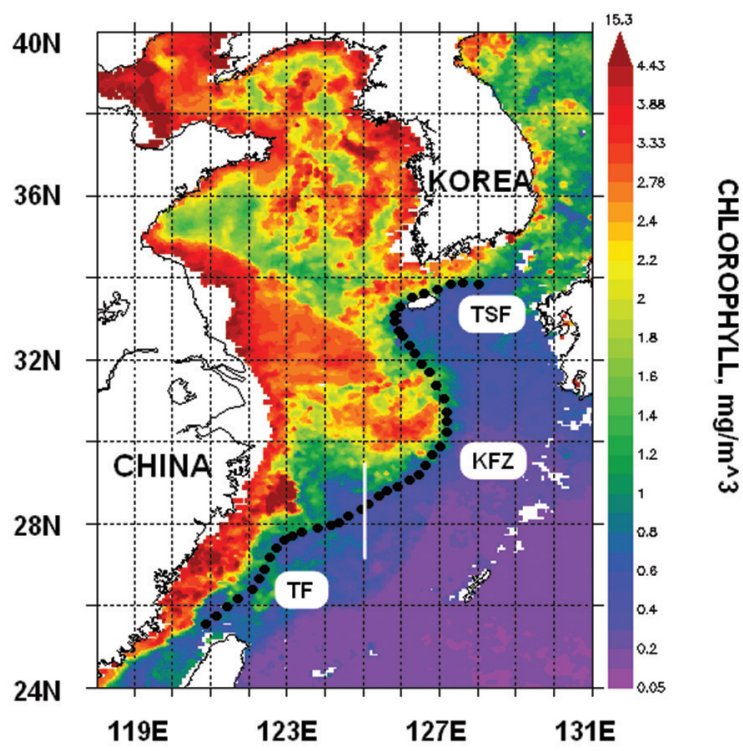

Fig. 7. Chlorophyll concentration in the Yellow and East China Seas in April 2004 (SeaWiFS data). Dotted line - seasonallyaveraged location of unified frontal structure for spring 2004 (March-May).

TF - Taiwan front, KFZ - Kuroshio frontal zone, TSF - Tsushima front. White vertical line - meridional section along the $125^{\circ} \mathrm{E}$ where the maximum value of $\mathrm{G}$ for February was calculated. 
$\left(1.5 \mathrm{mg} / \mathrm{m}^{3}\right)$ to burgundy $\left(15 \mathrm{mg} / \mathrm{m}^{3}\right)$, and oligotrophic oceanic waters corresponds to variations from blue to purple (less than $0.4 \mathrm{mg} / \mathrm{m}^{3}$ ). Cross-frontal exchange that is associated with the intensity of the front, can affect the lateral flow of nutrients as well as pollutants.

To study the long-term variability of the frontal system, we calculated magnitude of maximum meridional SST gradient $(G=|\partial(S S T) / \partial y|)$ along $125^{\circ} \mathrm{E}$ (see Fig. 7) in the area of Kuroshio frontal zone $\left(27^{\circ}-29^{\circ} \mathrm{N}\right)$ in February (the maximum intensity of the frontal zone) for the period of 1982-2009 from satellite data. An example of SST profile along $125^{\circ} \mathrm{E}$ for February 2005 is shown in Fig. 8. In this illustration, the temperatures in the range of $14.5-15.5^{\circ} \mathrm{C}$ corresponds to warm oceanic waters of Kuroshio, $10-11^{\circ} \mathrm{C}$ interval corresponds to the cold East China Sea waters and sharp temperature drop between them indicates the Kuroshio frontal zone.

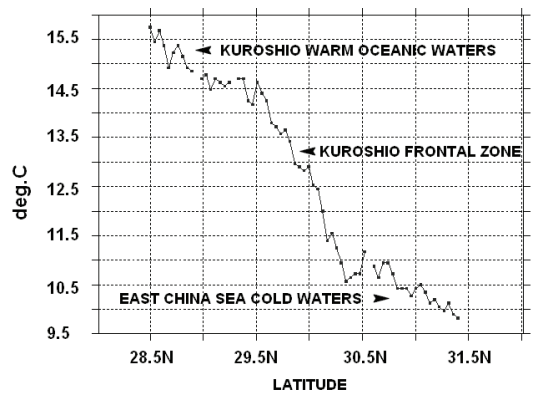

Fig. 8. SST profile along the $125^{\circ} \mathrm{E}$ in the area of $\mathrm{KFZ}$ in February 2005 (PATHFINDER data).

Time series of $\mathrm{G}$ presented in Fig. 9 (black line), confirms the presence of wellpronounced interannual variability with a period of $4-5$ years, consistent with the period of oscillation of the El Niño - Southern oscillation (ENSO) system. One of the most representative indicators of ENSO is the MEI (Multivariate ENSO Index) index. The MEI index is based on a combination of first six principal components of measured parameters (atmospheric pressure, zonal and meridional components of the wind, SST, air temperature and total cloudiness). Compared to indices based on anomalies of single parameter, such as the SOI (atmospheric pressure) or ONI (SST), the MEI index provides a more comprehensive and flexible description of the ENSO phenomenon (Wolter and Timlin 2011).

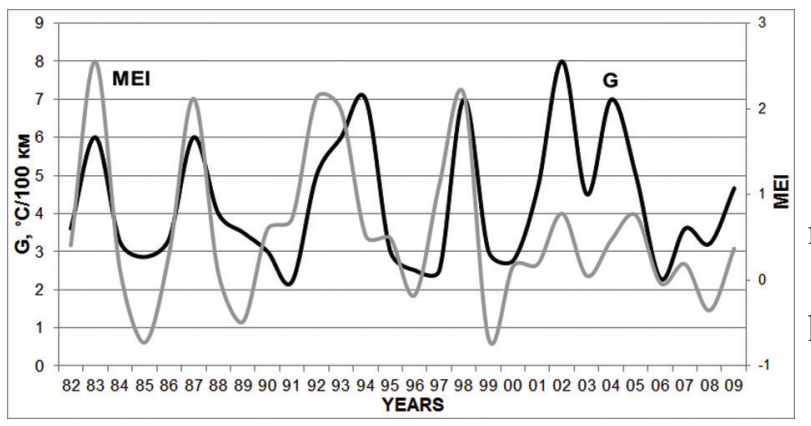

Fig. 9 confirms the presence of covariations between G (black line) and MEI index (grey line). We found suf ficiently high, statistically significant positive correlation
Fig. 9. Variability of the maximum meridional gradient of $S S T$ along the $125^{\circ} \mathrm{E}$ in the area of $\operatorname{KFZ~}\left(G,{ }^{\circ} \mathrm{C} / 100 \mathrm{~km}\right.$; black line) and MEI index (grey line) in February (after Kazmin, 2016; modified). 
$(\mathrm{R}=0.57, p<0.01)$ between $\mathrm{G}$ and the MEI index (Fig. 10). Since the positive values of MEI index correspond to El Niño events, a positive correlation means that increase in Kuroshio frontal zone intensity at the border of East China Sea coincides with the El Niño events.

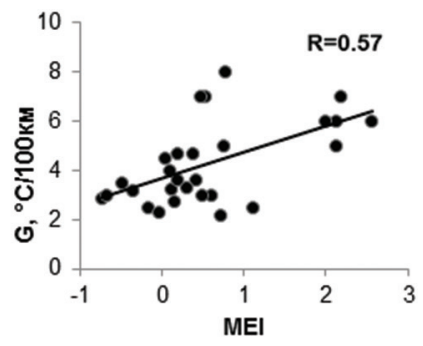

Fig. 10. Scatter diagram between MEI index (abscissa) and $\mathrm{G}\left({ }^{\circ} \mathrm{C} / 100 \mathrm{~km}\right.$; ordinate $)$ in February. Solid line indicates the linear regression curve between the two quantities with the correlation coefficient $R=0.57$.

Table. Comparative parameters of the local fronts in the Yellow and East China Seas

\begin{tabular}{|c|c|c|c|c|c|}
\hline \multirow[b]{2}{*}{$\begin{array}{l}\text { Front (according to the Fig. } 1 \\
\text { caption and text) }\end{array}$} & \multicolumn{2}{|c|}{ Spatial scales } & \multirow{2}{*}{$\begin{array}{l}\mathrm{SST} \\
\text { contrast, } \\
{ }^{\circ} \mathrm{C}\end{array}$} & \multirow{2}{*}{$\begin{array}{l}\text { SST gradient } \\
\text { (G; max syn- } \\
\text { optical value, } \\
\left.{ }^{\circ} \mathrm{C} / 100 \mathrm{~km}\right)\end{array}$} & \multirow[t]{2}{*}{ Features } \\
\hline & $\begin{array}{l}\text { width, } \\
\mathrm{km}\end{array}$ & $\begin{array}{l}\text { extension, } \\
\mathrm{km}\end{array}$ & & & \\
\hline $\begin{array}{l}\text { (2) Front between the WTC and } \\
\text { cold coastal current (TF) }\end{array}$ & $10-50$ & $450-500$ & $2-8$ & $10-40$ & $\begin{array}{l}\text { Stable orientation, } \\
\text { position and exten- } \\
\text { sion during the year. } \\
\text { Pronounced seasonal } \\
\text { variability. }\end{array}$ \\
\hline $\begin{array}{l}\text { (3) Front between the } \\
\text { south-western boundary of } \\
\text { YSWC and coastal current of } \\
\text { Yellow Sea }\end{array}$ & $5-30$ & $150-230$ & $2-3$ & $10-50$ & $\begin{array}{l}\text { Orientation, position and } \\
\text { extension are extremely } \\
\text { variable and depend on } \\
\text { the hydro-meteorological } \\
\text { conditions. }\end{array}$ \\
\hline $\begin{array}{l}\text { (4) Front between the } \\
\text { north-eastern boundary of } \\
\text { YSWC and south-western } \\
\text { branch of cold coastal current } \\
\text { along the western coast of } \\
\text { Korea }\end{array}$ & $25-40$ & $120-250$ & $2-3$ & $10-20$ & The same \\
\hline $\begin{array}{l}\text { (5) Front between the TSC and } \\
\text { cold coastal current along the } \\
\text { southern part of Korea peninsula } \\
\text { (TSF) }\end{array}$ & $20-60$ & $180-220$ & $2-3$ & $5-10$ & $\begin{array}{l}\text { Stable orientation, } \\
\text { position and exten- } \\
\text { sion during the year. } \\
\text { Pronounced seasonal } \\
\text { variability. }\end{array}$ \\
\hline (6) Shandong coastal front & $7-15$ & $100-140$ & $2-3$ & $20-60$ & $\begin{array}{l}\text { Orientation and position } \\
\text { are relatively stable; } \\
\text { existence and extension } \\
\text { depend on hydro-mete- } \\
\text { orological conditions. } \\
\text { Pronounced seasonal } \\
\text { variability. }\end{array}$ \\
\hline $\begin{array}{l}\text { (7) Yangtze River estuarine } \\
\text { front }\end{array}$ & Up to 90 & $200-300$ & up to 9 & 10 & $\begin{array}{l}\text { Parameters are strongly } \\
\text { dependent on the season } \\
\text { and hydro-meteorologi- } \\
\text { cal conditions. }\end{array}$ \\
\hline (8) Coastal tidal fronts & $15-25$ & $50-250$ & $4-5$ & $10-30$ & $\begin{array}{l}\text { Fronts occur in the } \\
\text { permanent locations, } \\
\text { have strong spatial and } \\
\text { temporal variability and } \\
\text { consist of separate small- } \\
\text { scale fronts. }\end{array}$ \\
\hline
\end{tabular}




\section{Conclusions}

An amplitude of the seasonal variability of major local fronts in Yellow and East China Seas depends on their location. In summer, the mean SST gradient $(G)$ has almost the same magnitude $\left(1-2^{\circ} \mathrm{C} / 100 \mathrm{~km}\right)$ for Taiwan front, Tsushima front and Shandong front due to the seasonal warming of the sea waters and subsequent weakening of the SST gradients (Fig. 2). However, in winter the magnitude of SST gradient for Taiwan front exceeds the corresponding values for Tsushima and Shandong fronts for a few (up to 5) times (Fig. 2). The reason is that warm Kuroshio waters first meet the very cold coastal current waters in Taiwan area. During the further propagation to the north-east, Kuroshio waters are cooling and temperature contrasts decrease. An amplitude of the seasonal variability of SST gradient in the Kuroshio frontal zone is much less $\left(0.6-2.1^{\circ} \mathrm{C} / 100 \mathrm{~km}\right.$; Fig. 6) than that one in the local fronts dew to its nature (large-scale climatological frontal zone).

Our results show that when climatological averaging is applied, the major fronts at the boundary of East China Sea (i.e., Taiwan front, Kuroshio frontal zone and Tsushima front) appear as unified dominating frontal structure. This structure is about $1200 \mathrm{~km}$ length, spreads along the continental shelf from Taiwan to Tsushima and separates productive sea waters from oligotrophic oceanic waters. Frontal structure exists as a persistent coherent feature during the whole year, but it reveals seasonal variability of the SST gradient intensity. Maximum intensity occurs during the cold period (October-March), when the SST contrasts between the warm waters of Kuroshio and cooling waters of East China Sea are the highest. In the warm period (May-August) temperature contrasts decrease and intensity of the frontal zone is reduced and surface manifestations of the Taiwan front disappear. However, in general, examined frontal structure in climatological terms maintains its coherence and stable position throughout the year and dominates in this area. Kuroshio frontal zone, being a part of this structure, reveals both seasonal (Fig. 6) and interannual (Fig. 9) variability with the periods consistent with the periods of oscillation of the ENSO system (4-5 years). Maximum intensity of the frontal zone coincides with the El Niño events.

Acknowledgments: This study in the part of data acquisition was supported by the RSF grant (project No. 14-50-00095). The results of data analysis were obtained in the framework of the state assignment of FASO Russia (theme No. 0149-2018-0003).

\section{References}

Beardsley R.C., Limeburner R., and Hu D. Structure of the Changjiang River plume in the East China Sea during June 1980. Proc. of the Int. Symp. on Sedimentation on the Continental Shelf with Special reference to the East China Sea, 1983, 12-16 Apr. Huangzhou, China, Beijing: China Ocean Press, 1983, Vol. 1, pp. 243-260.

Belkin I.M. and Cornillon P. SST fronts of the Pacific coastal and marginal seas. Pacific oceanography, 2003, Vol. 1(2), pp. 90-113. 
Belkin I.M., Cornillon P., and Sherman K. Fronts in Large Marine Ecosystems. Prog. Oceanography, 2009, doi:10.1016/j.pocean.2009.04.015.

Byun S.K. and Chang K.I. Tsushima Current Water at the Entrance of the Korea Strait in Autumn. Prog. In Oceanogr, 1988, Vol. 21, pp. 295-306.

Casey K.S., Brandon T.B., Cornillon P., and Evans R. The Past, Present and Future of the AVHRR Pathfinder SST Program. Oceanography from Space: Revisited, eds. V. Barale, J.F.R. Gower, and L. Alberotanza, Springer, 2010, doi: 10.1007/978-90-481-8681-5-16.

Chen C.T.A. Chemical and physical fronts in the Bohai, Yellow and East China Seas. Journal of Marine Systems, 2009, Vol. 78, pp. 394-410, doi:10.1016/j.jmarsys.2008.11.016.

Hickox R., Belkin I.M., and Cornillon. Climatology and seasonal variability of ocean fronts in the East China, Yellow and Bohai Seas from satellite SST data. Geophysical Research Letters, 2000, Vol. 27(18), pp. 2945-2948, doi:10.1029/1999GL011223.

Hu Dunxin. Upwelling and sedimentation dynamics. 1. The role of upwelling in sedimentation in Huanghai Sea and East China Sea - a description of general features. China J. Oceanol. Limnol, 1984, Vol. 2(2), pp. 12-19.

Kazmin A.S. Study of Fronts in the Yellow and East China Seas from Satellite Data. Soviet Journal of Remote Sensing, 1993, Vol. 10(3), pp. 495-506.

Kazmin A.S. The Frontal System at the Boundary of the East China Sea: Its Variability and Response to Large-Scale Atmospheric Forcing. Oceanology, 2016, Vol. 56, No. 4, pp. 465-469.

Kazmin A.S. Variability of the climatic oceanic frontal zones and its connection with the largescale atmospheric forcing. Progress in Oceanography, 2017, Vol. 154, pp. 38-48.

Kostianoy A.G. and Zatsepin A.G. The West African coastal upwelling filaments and cross-frontal water exchange conditioned by them. J. Mar. Sys, 1996, Vol. 7(2-4), pp. 349-359, doi: 10.1016/0924-7963(95)00029-1.

Kuroda Y., Hara T., and Misumi A. Across the East China Sea Shelf Edge by an Underwater Sliding Vehicle with CTD Sensors. Progr. in Oceanogr, 1988, Vol. 21, pp. 401-416.

Lie H.J. Tidal fronts in the Southeastern Hwanghae (Yellow Sea). Continental Shelf Res, 1989, Vol. 9(6), pp. 527-546.

Mao Hanil, Hu Dunxin, and Zhao Baoren. Mesoscale Eddy Movement in the Northern East China Sea. Chin. J. Oceanol. Limnol, 1983, Vol. 1(3), pp. 237-247.

Milliman J.D., Ya Hsueh, and Hu Dunxin. Tidal Phase Control of Sediment Discharge from Yangtze River. Estuarine, Coastal and Shelf Sci, 1984, Vol. 19, pp. 119-128.

Pan $J$., $Z u D$., and $X u J$. The structure of fronts and their causes in the coastal upwelling area off Zhejiang. Acta Oceanol. Sin, 1987, Vol. 6(2), pp. 177-189.

Sha $X$. and $X u B$. Quick reporting state of fishery and sea on the East China Sea and Yellow Sea with NOAA. Proc. of IGARSS' 88 Symp, 1988, Edinburg, Scotland, 13-16 Sept. Edinburg: 1988, pp. 1405-1408.

Wolter K. and Timlin M.S. El Niño/Southern Oscillation behaviour since 1871 as diagnosed in an extended multivariate ENSO index (MEI.ext). Int. Journal of Climatology, 2011, Vol. 31(7), pp. 1074-1087, doi: 10.1002/joc.2336.

$X u B$. and Sha $X$. A preliminary study on nearshore water in China with NOAA satellite images. Proc. of IGARSS'88 Symp., 1988, Edinburg, Scotland, 13-16 Sept., Edinburg: 1988, pp. 1413-1416.

Zheng $Q$. and Klemas $V$. Determination of winter temperature patterns, fronts and surface currents in the Yellow Sea and East China Sea from satellite imagery. Rem. Sens. of Environ, 1982, Vol. 12, pp. 201-210. 


\title{
ФРОНТЫ В ЖЕЛТОМ И ВОСТОЧНО-КИТАЙСКОМ МОРЯХ: ТЕМАТИЧЕСКОЕ ИССЛЕДОВАНИЕ
}

\author{
Казьмин А.С. \\ Институт океанологии им. П.П. Ширшова РАН, 117997, Москва, \\ Нахимовский проспект, д. 36, e-mail: akazmin@ocean.ru \\ Статья поступила в редакцию 24.05.2018, одобрена к печати 30.08.2018
}

\begin{abstract}
Для обновления и расширения знаний о структуре, мезомасштабных особенностях, сезонной и межгодовой изменчивости фронтов в Желтом и Восточно-Китайском морях использованы среднемесячные спутниковые измерения температуры поверхности моря (ТПМ) с высоким разрешением (данные PATHFINDER) за период 1982-2009 гг., а также отдельные спутниковые инфракрасные и видимые изображения. Представлены особенности общей циркуляции, процессов фронтогенеза и изложена феноменология фронтов. Документирована сезонная изменчивость отдельных наиболее значимых локальных фронтов. Основной результат заключается в том, что при применении климатологического осреднения фронты на границе Восточно-Китайского моря (Тайваньский фронт, фронтальная зона Куросио и Цусимский) образуют единую доминирующую фронтальную структуру. Эта структура протяженностью около 1200 км простирается вдоль континентального шельфа от о. Тайвань до о. Цусима и отделяет продуктивные морские воды от олиготрофных океанических вод. Эта фронтальная структура проявляется как устойчивая когерентная особенность в течение всего года. Однако она проявляет сезонную изменчивость интенсивности градиента ТПМ. Максимальная интенсивность наблюдается в холодное время года (январьапрель), когда контраст ТПМ между теплыми водами Куросио и охлаждающими водами Восточно-Китайского моря максимален. Для изучения долговременной изменчивости этой фронтальной системы рассчитан максимальный меридиональный градиент ТПМ в районе фронтальной зоны Куросио в феврале. Полученные результаты свидетельствуют о наличии выраженной межгодовой изменчивости градиента ТПМ с периодами, сопоставимыми с ENSO (4-5 лет). Найдена статистически значимая положительная корреляция $(R=0.57, p<0.01)$ между градиентом ТПМ и мультивариативным индексом ENSO (MEI).
\end{abstract}

Ключевые слова: морские фронты; мезомасштабные вариации; сезонная изменчивость; долгопериодные изменения; атмосферное воздействие; Желтое и Восточно-Китайское моря

\section{Литература}

Beardsley R.C., Limeburner R., Hu D. Structure of the Changiiang River plume in the East China Sea during June 1980. Proc. of the Int. Symp. on Sedimentation on the Continental Shelf with Special reference to the East China Sea. 1983. 12-16 Apr. Huangzhou, China // Beijing: China Ocean Press. 1983. Vol. 1. P. 243-260.

Belkin I.M., Cornillon P. SST fronts of the Pacific coastal and marginal seas// Pacific oceanography. 2003. Vol. 1(2). P. 90-113.

Belkin I.M., Cornillon P., Sherman K. Fronts in Large Marine Ecosystems // Prog. Oceanogr. 2009. DOI:10.1016/j.pocean.2009.04.015.

Byun S.K., Chang K.I. Tsushima Current Water at the Entrance of the Korea Strait in Autumn // Prog. Oceanogr. 1988. Vol. 21. P. 295-306. 
Casey K.S., Brandon T.B., Cornillon P., Evans R. The Past, Present and Future of the AVHRR Pathfinder SST Program // Oceanography from Space: Revisited, eds. V. Barale, J.F.R. Gower, and L. Alberotanza, Springer, 2010. DOI: 10.1007/978-90-481-8681-5-16.

Chen C.T.A. Chemical and physical fronts in the Bohai, Yellow and East China Seas // Journal of Marine Systems. 2009. Vol. 78. P. 394-410. DOI:10.1016/j.jmarsys.2008.11.016.

Hickox R., Belkin I.M., Cornillon P., Shan Z. Climatology and seasonal variability of ocean fronts in the East China, Yellow and Bohai Seas from satellite SST data // Geophysical Research Letters. 2000. Vol. 27(18). P. 2945-2948. DOI:10.1029/1999GL011223.

Hu Dunxin. Upwelling and sedimentation dynamics. 1. The role of upwelling in sedimentation in Huanghai Sea and East China Sea - a description of general features // China J. Oceanol. Limnol. 1984. Vol. 2(2). P. 12-19.

Kazmin A.S. Study of Fronts in the Yellow and East China Seas from Satellite Data // Soviet Journal of Remote Sensing. 1993. Vol. 10(3). P. 495-506.

Kazmin A.S. The Frontal System at the Boundary of the East China Sea: Its Variability and Response to Large-Scale Atmospheric Forcing // Oceanology. 2016. Vol. 56. No. 4. P. 465-469.

Kazmin A.S. Variability of the climatic oceanic frontal zones and its connection with the largescale atmospheric forcing // Progress in Oceanography. 2017. Vol. 154. P. 38-48.

Kostianoy A.G., Zatsepin A.G. The West African coastal upwelling filaments and cross-frontal water exchange conditioned by them // J. Mar. Sys. 1996. Vol. 7(2-4). P. 349-359. DOI: 10.1016/0924-7963(95)00029-1.

Kuroda Y., Hara T., Misumi A. Across the East China Sea Shelf Edge by an Underwater Sliding Vehicle with CTD Sensors // Progr. Oceanogr. 1988. Vol. 21. P. 401-416.

Lie H.J. Tidal fronts in the Southeastern Hwanghae (Yellow Sea) // Continental Shelf Res. 1989. Vol. 9(6). P. 527-546.

Mao Hanil, Hu Dunxin, Zhao Baoren. Mesoscale Eddy Movement in the Northern East China Sea // Chin. J. Oceanol. Limnol. 1983. Vol. 1(3). P. 237-247.

Milliman J.D., Ya Hsueh, Hu Dunxin. Tidal Phase Control of Sediment Discharge from Yangtze River // Estuarine, Coastal and Shelf Sci. 1984. Vol. 19. P. 119-128.

Pan $J ., Z u D$., Xu $J$. The structure of fronts and their causes in the coastal upwelling area off Zhejiang // Acta Oceanol. Sin. 1987. Vol. 6(2). P. 177-189.

Sha $X$., Xu B. Quick reporting state of fishery and sea on the East China Sea and Yellow Sea with NOAA // Proc. of IGARSS'88 Symp. 1988. Edinburg, Scotland, 13-16 Sept. Edinburg: 1988. P. 1405-1408.

Wolter K., Timlin M.S. El Niño/Southern Oscillation behaviour since 1871 as diagnosed in an extended multivariate ENSO index (MEI.ext) // Int. Journal of Climatology. 2011. Vol. 31(7). P. 1074-1087. DOI: 10.1002/joc.2336.

$X u$ B., Sha $X$. A preliminary study on nearshore water in China with NOAA satellite images // Proc. of IGARSS'88 Symp. Edinburg, Scotland, 13-16 Sept. 1988. Edinburg: 1988. P. 1413-1416.

Zheng $Q$., Klemas $V$. Determination of winter temperature patterns, fronts and surface currents in the Yellow Sea and East China Sea from satellite imagery // Rem. Sens. of Environ. 1982. Vol. 12. P. 201-210. 